\title{
Detection of invA Gene in Isolated Salmonella from Marketed Poultry Meat by PCR Assay
}

\author{
Indu Sharma* and Kashmiri Das
}

Microbiology Department, Assam University, Silchar-788011, India

\begin{abstract}
Background: The aims of the current study were to detect the invA gene from chicken samples meant for human consumption from N.E India.
\end{abstract}

Materials and method: After Salmonella sp. identification with culture method, PCR assay were developed for detection of pathogenic genes and antibiotic resistance genes of Salmonella sp.

Results: Salmonella was detected in 80 samples of poultry carcasses from main poultry markets in Silchar, Assam, N.E India. A total of 40 Salmonella isolates were found in chicken samples $(43 \%)$ and the isolates had a growth on brilliant green agar and De-oxycholate citrate agar medium, were oxidase negative and catalase positive and exhibited no changes in the colour of the medium with $100 \%$ motility. All the strains were subjected to Salmonella-specific gene (invA) and were confirmed as Salmonella positive by the predicted product of 284-bp DNA fragment. Salmonella isolates recovered from poultry samples were tested for antibiotic susceptibility against 5 selected antibiotics of which ciprofloxacin was observed to be highly susceptible $(77.5 \%)$.

Conclusion: Our results recommended the use of PCR for detection of pathogenic genes of bacteria as a safe, rapid, and accurate method in laboratories. High levels of Salmonellosis infections in poultry farms has raised an eye amongst the poultry management personnel's to consider various effective control programs to prevent the economic loss resulting from mortality and spreading of infection.

Keywords: Poultry meat; Salmonella; PCR; InvA gene

\section{Introduction}

Poultry provides an immense supply of food for the entire world's population where poultry meat and eggs in majority are all time preferred to other kinds of animal food products for a variety of reasons, but most of these have been implicated as a major source of Salmonella infection in human [1]. Today, reports on mishandling of poultry products and raw poultry carcasses, uncooked poultry meat are one of the frequent causes of human infection caused by Salmonella species [2]. Also, a number of Salmonella serotypes can be transferred to poultry from sources, such as feedstuffs, breeding flocks, rodents, and wild birds, etc. of which may act as an important hindering factor for the economy and growth of a country. Thus in the present time, several new techniques in this regard have been developed for the rapid detection of Salmonella serovars such as selective culture medium and enzymelinked immunosorbent assay [3]. However, today the Polymerase Chain Reaction (PCR) method has emerged as a powerful, rapid and a reliable tool for detection and identification of food- borne pathogens such as Salmonella. Malorny [4] where several chromosomal genes including invA are target genes for PCR amplification of Salmonella species [5]. The invA, gene of Salmonella contains those sequences that are unique to this genus and has been proved as a suitable PCR target with potential diagnostic applications [6]. Thus, keeping the above in view, the present investigation highlights the screening of poultry meat samples for Salmonella sp. and their confirmation by invA specific PCR methods.

\section{Materials and Methods}

\section{Clinical isolates and phenotypic identification}

A total of 80 poultry samples were collected from various parts of Silchar, Cachar District, Assam, comprising of meat, liver, intestine scrapings and faecal materials. The samples mostly belonged to highly crowded areas, slaughter houses, swabs from butchers knife used for cutting chicken. Samples were aseptically enriched in selenite $\mathrm{F}$ broth (Himedia) and incubated at $37^{\circ} \mathrm{C}$ for 24 hours. A loopful from the broth was then streaked on brilliant green agar (Himedia) and Deoxycholate citrate agar (Himedia) for further incubation at $37^{\circ} \mathrm{C}$ for 24 hours. The distinct isolated colonies were identified on the basis of their morphological and biochemical characters. The shape and colours of the colonies were examined under the microscope after Gram staining. Isolates were biochemically confirmed for the activities of oxidase, catalase, methyl red, voges-prauskauer test, urease, motility, indole production, citrate utilization, TSI and sugar fermentation tests through a series of conventional biochemical tests. Colonies that depicted biochemical reactions like Salmonella were transferred to nutrient agar slant (Himedia) and incubated at $37^{\circ} \mathrm{C}$ for $24 \mathrm{hrs}$.

\section{Antibiotic susceptibility test}

Antibiotic susceptibility of the isolates was assayed according to Kirby-Bauer disc diffusion method on Mueller-Hinton agar (MHA) [7]. The isolates were freshly inoculated on saline water for detection of turbidity via comparison with $0.5 \mathrm{Mc}$. Farland solution $(1.5 \times 108 \mathrm{CFU} / \mathrm{ml})$. The antibiotic disks used were of HI-MEDIA Laboratories, Mumbai, India, consisting of the following: Kanamycin $(30 \mu \mathrm{g})$, Ciprofloxacin $(5 \mu \mathrm{g})$, Ampicillin $(25 \mu \mathrm{g})$, Norfloxacin $(10 \mu \mathrm{g})$ and Nalidixic acid $(30 \mu \mathrm{g})$. Positive tests were indicated by zones of

*Corresponding author: Indu Sharma, Microbiology department, Assam University, Silchar-788011, India, Tel: +919435724517; E-mail: drsharma7652@gmail.com

Received January 13, 2016; Accepted February 03, 2016; Published February 09,2016

Citation: Sharma I, Das K (2016) Detection of invA Gene in Isolated Salmonella from Marketed Poultry Meat by PCR Assay. J Food Process Technol 7: 564. doi:10.4172/2157-7110.1000564

Copyright: ( 2016 Sharma I, et al. This is an open-access article distributed unde the terms of the Creative Commons Attribution License, which permits unrestricted use, distribution, and reproduction in any medium, provided the original author and source are credited. 
inhibition which were measured by using the zone size interpretative tables provided by the manufacturer of the discs.

\section{Genotypic screening of $i n v A$ gene from isolated strain by PCR assay}

DNA of Salmonella isolates was extracted and purified using Genomic DNA Mini Kit (cultured cell).

Primers set and PCR amplification program: The primers (Forward and Reverse) used in PCR were specific for invA gene which was chosen according to Rahn [6]. The sequence of primer used in this study is presented in Table 1.

\section{Electrophoresis of PCR products}

PCR for amplification of $i n v A$ gene was performed using $12.5 \mu \mathrm{l}$ of Tag Green Master Mix 2x DNA polymerase [8], specific primers for invA gene ( $1 \mu \mathrm{l}$ forward and $1 \mu \mathrm{l}$ reverse), $2 \mu \mathrm{l}$ of DNA extract as a template, $8.5 \mu$ of nuclease free water to make the final reaction volume up to $25 \mu \mathrm{l}$. The PCR conditions started with thermocycler (Eppendorf) program that is initial denaturation at $95^{\circ} \mathrm{C}$ for 2 minutes, 34 cycles of denaturation at $95^{\circ} \mathrm{C}$ for 15 seconds, $45^{\circ} \mathrm{C}$ for 1 minute, and $72^{\circ} \mathrm{C}$ for 45 seconds and final extension at $72^{\circ} \mathrm{C}$ for 7 minutes.

\section{Agarose gel electrophoresis}

Five microliters of the reaction mixture and $1 \mu \mathrm{l}$ marker DNA (100 bp DNA ladder mix; MBI Fermentas, USA) mixed separately with 1 $\mu \mathrm{l}$ of $6 \mathrm{X}$ gel loading dye (MBI Fermentas, USA) and were analyzed by submarine gel electrophoresis in $1.2 \%$ agarose (Hi-Media, Mumbai, India) at $60 \mathrm{~V}$ for 1 hour and $20 \mathrm{~min}$. or until the second dye marker had run 3/4th of the gel. The reaction products were visualized with UV light after staining with ethidium bromide. The identities of the amplicons were confirmed by comparison of the amplicon sizes with the predicted sizes and photographed [8].

\section{Results}

A total of 80 chicken samples were procured for this study, of which 40 isolates of Salmonella sp. were recovered. Table 2 represents the total number of isolates and their percentage.
All the 40 isolates had a growth on brilliant green agar and Deoxycholate citrate agar medium, were oxidase negative and catalase positive and exhibited no changes in the colour of the medium. $100 \%$ motility was observed in all the isolates; indole and methyl-red tests were observed as positive and voges-Proskauer test as negative; all of them represented citrate utilization, urease test as negative, were non-lactose fermenters on MacConkey agar medium and fermented glucose, fructose and maltose. TSI was observed as $\mathrm{K} / \mathrm{A}^{\mathrm{G}+\mathrm{H} 2 \mathrm{~S}}+$. All the 40 isolates were identified as Salmonella organisms.

Forty Salmonella isolates recovered from poultry samples were tested for antibiotic susceptibility against 5 selected antibiotics. Percentages of Salmonella isolates susceptible to antibiotics are represented in Table 3 .

Forty Salmonella strains were isolated from poultry specimens, by culturing in selenite $\mathrm{F}$ and then transferring to Salmonella-Shigella agar, when subjected to Salmonella specific-PCR using primers invA F and $i n v A \mathrm{R}$ where all isolates including positive control and a single 284 bp amplified DNA fragment, on 1.2\% agarose gel (Figure 1).

\section{Discussion}

The present study evaluated the microbial quality of poultry meat sold at various retail markets of Silchar, were heavily contaminated with Salmonella sp. (43\%) [9-11]. Presence of bacteria in meat is of great public health concern [12] indicating a potential breakdown of hygiene at various stages of the food processing and distribution chain and/or a lack of refrigeration of meat. As observed during the course of this study, the methods of slaughtering of animal are responsible for this microbial contamination. Traditional method of butchering using knives and cutting lines appears more capable of minimizing faecal contamination then modern mechanized system which are manned by a team of operators. This was inferred because poultry samples collected from the local abattoir were less contaminated, than those collected from the areas where modern equipment is used [13].

Biochemical reactions are very important for speciating the isolates, while isolates could get a correct identification only when based on genetic methods. In the present study, all the 40 (43\%)

\begin{tabular}{|c|c|c|c|}
\hline Name of primer & Target gene & Primer sequence (5'-3') & Amplified product size \\
\hline InvA F & invA & GTGAATTATCGCCACGTTCGGGCAA & Reference \\
\cline { 1 - 2 } InvA R & & TCATCGCACCGTCAAAGGAACC & Rahn et al. [15] \\
\hline
\end{tabular}

Table 1: Sequences of primers for invA gene.

\begin{tabular}{|c|c|c|c|c|}
\hline SL No. & Samples from different parts of poultry & Samples procured & Total no. of isolates isolated & Percentage of Salmonella sp \\
\hline & Meat & 29 & 15 \\
\hline & Liver & 23 & 12 \\
\hline & Scrapping & 11 & 5 \\
\hline & Fecal & 17 & 8 \\
\hline & Total & 80 & $47 \%$ & 40 \\
\hline
\end{tabular}

Table 2: Percentage of Salmonella sp. contamination in poultry chicken samples from the different areas of Silchar.

\begin{tabular}{|c|c|c|}
\hline Antibiotics & Total susceptible isolates & \% of susceptible isolates \\
\hline Ampicillin & 25 & $62.5 \%$ \\
\hline Ciprofloxacin & 31 & $77.5 \%$ \\
\hline Kanamycin & 30 & $75 \%$ \\
\hline Norfloxacin & 23 & $57.5 \%$ \\
\hline Nalidixic acid & 26 & $65 \%$ \\
\hline
\end{tabular}

Table 3: Percentages of Salmonella isolates susceptible to antibiotics from poultry samples. 

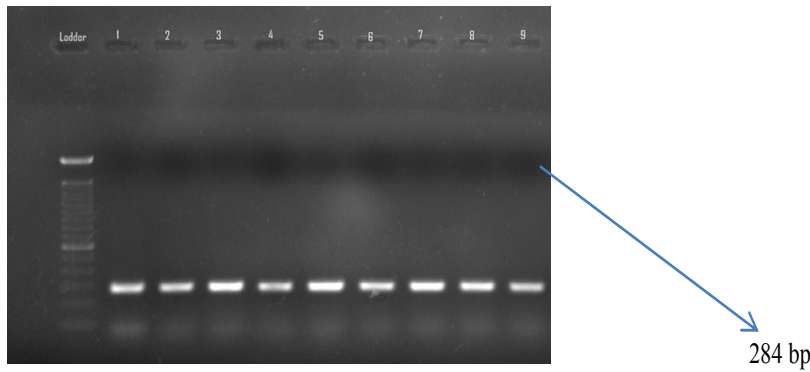

Figure 1: Gel image showing amplification of invA gene. Ladder used is 100 bp ladder. Lanes $1,2,3,4,5,6,7,8$ and 9 exhibits the amplified invA gene (284 bp).

isolates exhibited typical biochemical characteristics of Salmonella on the basis of IMViC reaction, gas production and sugar fermentation as per standard techniques. All the isolates tested negative oxidase, positive catalase, positive indole in typtone broth, positive methyl red, negative Voges-Proskauer, urease negative and citrate positive tests and fermented glucose, fructose and maltose.

Today, the frequencies of bacterial strains resistant to antimicrobial agents have increased dramatically in the environment as a consequence of the wide spread use of drugs [14]. A significant public health concern and the possibility of transfer of resistant genes between bacteria in the natural habitats have attracted attention. In the present study, antimicrobial susceptibility pattern against 5 antibiotics was carried out for 40 Salmonella isolates of which ciprofloxacin was $77.5 \%$ susceptible, whereas kanamycin exhibited (75\%) susceptibility, nalidixic acid (65\%), ampicillin (62.5\%) and norfloxacin (52.5\%). It was observed that norfloxacin which was routinely used in present prognosis was the least susceptible antimicrobial agent found in the present study. Also, this is the first report on the prevalence of Salmonella, determining its antimicrobial-resistance pattern along with detection of invA gene of Salmonella from poultry farms and slaughter houses of this geographical area. In the current study, the overall prevalence of Salmonella and fecal shedding of Salmonella was lower in organized farms than the slaughter houses. Despite the use of selective broth, we recovered higher proportions of Salmonella (43\%) from the both clinical as well as post-mortem samples.

The present study supports the ability of these specific primer sets to confirm the isolates as Salmonella. All PCR products of isolates included positive control, screened by PCR, resulted in $284 \mathrm{bp}$ amplified fragment. No amplified DNA fragments were obtained from nonSalmonella species. The ability of Salmonella specific primers to detect Salmonella species rapidly and accurately is primarily due to the primer sequences that are selected from the gene inv $\mathrm{A}$ [15]. The inv $\mathrm{A}$ gene codes for protein in inner membrane of bacteria, which is necessary for invasion to epithelial cells [16]. The PCR assay carried out in this study for the detection of the invA genes in 40 Salmonella isolates from poultry meat samples was present in 22 isolates (55\%). These findings are in agreement with the earlier reports [17-20]. Furthermore it has been observed that this gene is involved in the invasion of the cells of the intestinal epithelium and is present in pathogenic Salmonella. Therefore for salmonellosis to occur it is important that a gene responsible for invasion must be present. This gene is essential for full virulence in Salmonella and is thought to trigger the internalization required for invasion of deeper tissue [21].

\section{Conclusion}

High levels of Salmonellosis infections in poultry farms has raised an eye amongst the poultry management personnel's to consider various effective control programs to prevent the economic loss resulting from mortality and spreading of infection. In the present work, PCR based methods with genus-specific primers belonging to invA, proved to be quick, specific and sensitive and certain in identification and confirmation of Salmonella isolates.

\section{Acknowledgment}

We are grateful to the Department of Microbiology, Assam University in regard to financial assistance for completion of this investigation.

\section{References}

1. Amavisit P, Browning GF, Lightfood D, Anderson CS (2001) Rapid PCR detection of Salmonella in horse faecal samples. Vet Microbiol 79: 63-74.

2. Antunes P, Reu C, Sousa JC, Peixe L, Pestana N (2003) Incidence of Salmonella from poultry products and their susceptibility to antimicrobial agents. Int J Food Microbiol 82: 97-103.

3. Bauer AW, Kirby WM, Sherris JC, Turck M (1966) Antibiotic susceptibility testing by a standardized single disk method. Am J Clin Pathol 45: 493-496.

4. Baumgartner A, Heirnann P, Schmid H, Liniger M, Simmen A, et al. (1992) Salmonella contamination of poultry carcasses and human salmonellosis. Archiv fuer Lebensmittelhygiene 43: 123-124.

5. Darwin KH, Miller VL (1999) Molecular basis of the interaction of Salmonella with the intestinal mucosa. Clin Microbiol Rev 12: 405-428.

6. Jamshidi A, Bassami MR, Afshari-Nic S (2009) Identification of Salmonella spp and Salmonella typhimurium by a multiplex PCR-based assay from poultry carcasses in Mashhad-Iran. Int J Vet Res 3: 43-48.

7. Jerngklinchan J, Koowatananukul C, Daengprom K, Saitanu K (1994) Occurrence of salmonellae in raw broilers and their products in Thailand Journal of Food Protection 57: 808-810.

8. Khan AA, Cheng CM, Khanh TV, Summage-West C, Nawaz MS, et al (2006) Characterization of class 1 integron resistance gene cassettes in Salmonella enterica serovars Oslo and Bareilly from imported seafood Journal of Antimicrobial Chemotherapy 58: 1308-1310.

9. Kinsella KJ, Prendergast DM, McCann MS, Blair IS, McDowell DA, et al.(2009) The survival of Salmonella enterica serovar Typhimurium DT104 and total viable counts on beef surfaces at different relative humidities and temperatures. J Appl Microbiol 106: 171-180.

10. Lampel KA, Orlandi PA, Kornegay L (2000) Improved template preparation for PCR-based assay for detection of food-borne bacterial pathogens. App Environ Microbiol 66: 4539-4542.

11. Malorny B, Hoorfar J, Bunge CR, Helmuth R (2003) Multicenter validation of the analytical accuracy of Salmonella PCR: towards an international standard. App Environ Microbiol 69: 290-296.

12. Nagappa K, Tamuly S, Brajmadhuri, Saxena MK, Singh SP, et al. (2007) Isolation of Salmonella Typhimurium from poultry eggs and meat of Tarai region of Uttaranchal. IJBT 6: 407-409.

13. Nashwa MH, Mahmoud AH, Sami SA (2009) Application of multiplex polymerase chain reaction (MPCR) for identification and characterization of Salmonella Enteritidis and Salmonella Typhimurium. Journal of Applied Sciences Research 5: 2343-2348

14. Panisello PJ, Rooney R, quantick PC, Stanwell-Smith R (2000) Application of foodborne disease outbreak data in the development and maintenance of HACCP system. International Journal of Food Microbiology 59: 221-234.

15. Rahn K, De Grandis SA, Clarke RC, Curtiss R, Gyles CL, et al. (1992) Amplification of an invA gene sequence of Salmonalla typhimurium by polymerase chain reaction as a specific method of detection of Salmonella. Molecular and Cellular Probes 6: 271-279.

16. Shanmugasamy M, Velayutham T, Rajeswar J (2011) invA gene specific PCR for detection of Salmonella from broilers. Veterinary World 4: 562-564. 
Citation: Sharma I, Das K (2016) Detection of invA Gene in Isolated Salmonella from Marketed Poultry Meat by PCR Assay. J Food Process Technol 7: 564. doi:10.4172/2157-7110.1000564

Page 4 of 4

17. Trafny EA, Kozlowska K, Szpakowska M (2006) A novel Multiplex PCR assey for the detection of Salmonella enteric serovar Enteritidis in human faeces. Letters in Applied Microbiology 43: 673-679.

18. Uyttendaele MR, Debevere CM, Lips RM, Neyts KD (1998) Prevalence of Salmonella in poultry carcasses and their products in Belgium. International Journal of Food Microbiology 40: 1-8.

19. Whyte P, Meglli K, Collins D, Gormely E (2002) The prevalence and PCR detection of Salmonella contamination in raw poultry. Veterinary Microbiology 89: 53-60.
20. Xu J, Moore JE, Murphy PG, Millar BC, Elborn JS, et al. (2004) Early detection of Pseudomonas aeruginosa-comparison of conventional versus molecular (PCR) detection directly from adult patients with cystic fibrosis (CF). Annals of clinical Microbiology and Antimicrobials.

21. Zahraei T, Mahzoonae MR, Ashrafi A (2006) Ampllification of invA gene of Salmonella by polymerase chain reaction (PCR) as a specific method for detection of Salmonella. Journal of the Faculty of Veterinary Medicine University of Tehran 6: 195-199. 